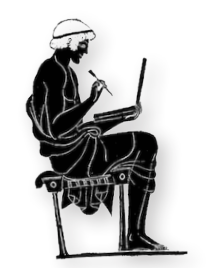

\title{
Revendo a poesia no centro do mundo
}

Reviewing the poetry at the center of the world

Fábio Paifer Cairolli ${ }^{1}$

e-mail: cairolli@yahoo.com.br orcid: https://orcid.org/0000-0002-3987-937X

DOI: https://doi.org/10.25187/codex.v9i1.41140

Resenha de MARTINS, P; HASEGAWA, A. P.; OliVA NETO, J. A. (orgs.) Augustan Poetry, New Trends and Revaluations. São Paulo: FFLCH-USP / Humanitas / SBEC, 2019. xx p.

Palavras-chave: poesia augustana; Virgílio; Horácio; Propércio; Ovídio

Keywords: Augustan poetry; Virgil; Horace; Propertius; Ovid

Em uma semana iluminada pelo agradável sol do inverno paulistano, em uma daquelas conjunções de astros que Horácio, num famoso poema, desaconselhava suas amadas a perscrutar, reuniram-se nas dependências da Casa Guilherme de Almeida pesquisadores procedentes dos mais variados centros de excelência, brasileiros e estrangeiros, em estudos clássicos, pensadores da mais variada perspectiva, ali trazidos para realizar um objetivo ambicioso: apresentar à comunidade científica um panorama do que vinha sendo pensado de novo a respeito da poesia produzida, em latim, durante o período chamado augustano.

Era um objetivo ambicioso. E não apenas pela sua abrangência cronológica, já que compreende as mais de cinco décadas em que Augusto foi um protagonista na arena política de Roma (e, portanto, interferente nos rumos do que era dito nas letras latinas), desde seu surgimento precoce como herdeiro político de Júlio César até sua morte, avançado em anos, depois de ter revolucionado a

\footnotetext{
${ }^{1}$ Professor de Língua e Literatura Latina da Universidade Federal Fluminense, Niterói, Brasil.
} 
administração romana e por longos quarenta e quatro anos ter sido seu único senhor. A perspectiva do encontro era especialmente ambiciosa porque no referido período floresceram algumas das vozes mais brilhantes da poesia universal. Com efeito, a tríade Virgílio-Horácio-Ovídio, todos ativos sob a égide do princeps, já foi classificada por muitos como os principais poetas das letras latinas, motivadores de que, em outros tempos e segundo critérios teóricos hoje já um pouco deixados de lado, esse período tenha sido chamada de Era de ouro da literatura latina.

Clássicos máximos, no topo de um cânone supranacional, há vinte séculos sendo continuamente eleitos como leituras fundamentais, haveria ainda espaço para que coisas novas pudessem ser descobertas em seus versos? A crer nas palavras de Ítalo Calvino, para quem o texto digno do adjetivo clássico nunca termina de dizer o que tinha a dizer, e, além disso, se revelam mais inéditos, inesperados e novos, quanto mais forem lidos, a resposta para essa pergunta foi sim.

E foi para isso que os organizadores reuniram, naquele inverno de 2015, tão distinto pessoal. Entre os dias 8 e 10 de julho daquele ano, no contexto do V Colóquio Internacional "Visões da Antiguidade Clássica", deram-se as apresentações e os debates que originaram o livro que ora discutimos. E dos cinco poetas que foram discutidos no período, cada um deles um universo próprio que se desdobra em uma multidão de livros, gêneros e temas, pouco foi deixado de lado.

O volume em questão testemunha o sucesso daquele evento em apresentar novas visões inovadoras sobre o tema abordado. Do que se discutiu naqueles dias surgiram as contribuições reunidas nesse livro, divididas em três eixos temáticos, baseados nos gêneros aos quais cada poeta se dedicou e que, desde a antiguidade, é um dos critérios preferenciais de organização e interpretação do texto poético clássico. Assim, a primeira seção trata da Elegia de Tibulo, Propércio e Ovídio; a segunda, dos gêneros lírico, iâmbico e satírico, assim reunidos por terem sido praticados por Horácio (e só por ele no período augustano); a terceira, por fim, da épica de Virgílio e Ovídio.

$\mathrm{Na}$ primeira seção, os diversos artigos que investigam a obra de Propércio, por exemplo, fazem uma abordagem complementar: por um lado, Paolo Fedeli, em Dalla città deglia amori alla città que cresce: Properzio e la Roma augustea, mostra como, sendo a cidade uma projeção simbólica daquilo que o enunciante é ou acredita ser, a Roma de Propércio se desenvolve e se modifica ao longo dos seus textos, acompanhando a transição da persona do autor, de cantor sujeito ao único amor da puella Cíntia nos primeiros livros a poeta experimental, etiológico e possivelmente engajado com o regime em suas últimas composições; na direção contrária, isto é, partindo da realidade histórica em direção à ficção poética, desenvolve-se a contribuição de Paulo Martins, A rumour in Propertius. Aqui, partindo-se da inegável existência histórica de caracteres como Augusto, Mecenas e o próprio Propércio, será observada a transformação de informações históricas, especificamente a legislação augustana que buscava regulamentar as relações matrimoniais, em matéria poética na elegia II, 7, desse autor, tradicionalmente referida como testemunho dos sentimentos do poeta em relação ao princeps. 
Complementar a essas duas vozes, mas agora partindo da perspectiva ovidiana do tema, é o artigo de Gianpiero Rosati, Imperii Roma deumque locus: la Roma angustea come città celeste. Nele, o percurso que se estabelece, partindo da cidade, não é mais em direção ao indivíduo, mas em direção a ao super-indivíduo, isto é, o divino: nas abundantes referências que o poeta de Sulmona faz ao tema, Rosati demonstra como a assimilação do Olimpo, cidade dos deuses, a Roma, cidade dos homens, é uma via de duas mãos, dado que a um só tempo romaniza os deuses e diviniza os humanos, ou mais especificamente Augusto, deus vivo na terra, e forma base para uma abundante tradição discursiva que englobará autores como Marcial e Estácio, e servirá de substrato para a cidade divina de Santo Agostinho quatro séculos depois.

Os três exemplos apontados mostram como o pensamento de intelectuais com perspectivas e prioridades diferentes, atuando em margens opostas do Atlântico, se entretecem e convergem no volume para que uma nova imagem se forme, multifacetada e periegética, nova, da obra de Propércio.

E não é um caso único, nem a convergência se resume a temas ou autores específicos. Em determinados temas gerais, como a métrica, as múltiplas visões apresentadas tiveram perspectivas complementares. Por um lado, João Batista Toledo Prado discute a relação entre os padrões rítmicos da poesia latina e suas camadas de sentido, aplicando suas observações a um texto elegíaco, o poema I, 10 de Tibulo. De maneira complementar, também voltou suas atenções à métrica Érico Nogueira, enfocando por sua vez nas Odes de Horácio. Aqui, não apenas a distribuição dos autores é complementar, mas a abordagem: Prado é extremamente cioso das implicações que o sistema fonológico da língua em que o texto é composto tem para as relações de sentido; Nogueira está interessado na relação do sistema rítmico do latim com o das línguas de chegada, confrontado suas propostas de tradução do poeta venusino ao português com experimentos em inglês e alemão.

Os exemplos apontados, apenas cinco dos quinze textos que compõem a coleção, dão o testemunho da vibrante relevância dos estudos clássicos, protagonistas da construção de um saber vanguardista e transdisciplinar, levando para a observação da poesia instrumental que vai da fonética à filosofia, do retórico ao antropológico, sem deixar de recorrer, renovando-os, aos conceitos de filologia e teoria literária que tradicionalmente têm instrumentalizado a investigação da poesia latina.

O volume de que tratamos, portanto, é sintomático das novas perspectivas e da inter-relação entre o que se pensa sobre os poetas augustanos na academia brasileira e nos mais renomeados centros da Europa e das Américas. Sendo os autores referenciais, e tendo discutido num ambiente de cordial generosidade, não é de espantar que o desejo dos organizadores de ver as ideias ali expostas renascerem logo se cumpra. A bem da verdade, já tem se cumprido: antes mesmo de o volume impresso vir à luz, nós mesmos voltamos para nosso posto de trabalho com o embrião de uma pesquisa sobre a urbe, agora, na poesia de Marcial. E outros virão.

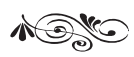

